\title{
PLCD3 Gene
}

National Cancer Institute

\section{Source}

National Cancer Institute. PLCD3 Gene. NCI Thesaurus. Code C116272.

This gene is involved in second messenger synthesis. 